\title{
Morphotaxonomic evaluation of the relationship between four species of Crassocephalum (Moench.) S. Moore (Asteraceae) in southwestern Nigeria
}

\author{
A. S. OYELAKIN ${ }^{1 *}$ and M. S. AYODELE ${ }^{2}$ \\ ${ }^{1}$ Department of Biology, Federal University of Technology, Akure P. M. B. 704, Akure, Ondo State, Nigeria. \\ ${ }^{2}$ Department of Biological Sciences, Federal University of Agriculture, Abeokuta P. M. B. 2240, Abeokuta, Ogun State, \\ Nigeria.
}

Accepted 30 August, 2013

\begin{abstract}
The morphotaxonomic identity of Crassocephalum biafrae (Oliv. \& Hiern.) S. Moore was compared with other three taxa namely: Crassocehalum crepidioides (Benth.) S. Moore, Crassocephalum rubens (Juss.ex.Jacq.) S. Moore and, Crassocephalum togoense C.D. Adams in the genus Crassocephalum tribe Senecioneae; with the intent of establishing some delimiting features truly uniting (or otherwise) the taxa. $C$. biafrae was clearly separable from $C$. crepidioides, $C$. rubens and $C$. togoense on the basis of growth habit, stem texture, leaf shape, size, apex, and texture. Other morphological evidences separating these are well documented. Morphological characters considered being of taxonomic significance were widely manifested by $C$. biafrae as differing from the other three species. There was evidence of more similarities and overlaps in morphological attributes of these other three species. However, the somewhat narrow morphological similarities exhibited by $C$. biafrae to the other three species suggest infrageneric segregation in the genus. We hereby suggest the infrageneric group for $C$. biafrae from the genus Crassocephalum based on its strikingly distinctive morphological characteristics.
\end{abstract}

Key words: Crassocephalum, morphotaxonomic identity, Southwestern Nigeria.

\section{INTRODUCTION}

The genus Crassocephalum (Moench.) S. Moore contains dicotyledonous plants that belong to the family Asteraceae, and tribe Senecioneae (Hutchinson and Dalziel, 1963). For tropical Africa, 24 species were reported with fifteen of these species in West Africa. In Nigeria, nine species were described. Of these, four species available for this study are endemic to SouthwesternNigeria. Thefourspeciesare Crassocephalum crepidioides, Crassocephalum biafrae, Crassocephalum rubens and, Crassocephalum togoense (Adams, 1963; Hutchinson and Dalziel, 1963; Olorode and Okoli, 1978).

Members of the genus are constantly identified as erect, little branched herbs with pubescent lyrate-pinnatifid, acute, coarsely serrated leaves and terminal heads with only disc florets (Hutchinson and Dalziel, 1963). A basic taxonomic identification of $C$. rubens, $C$. crepidioides, $C$. biafrae and $C$. togoense as different species of Crassocephalum found in Southwestern Nigeria was provided (Hutchinson and Dalziel, 1963; Adams, 1963; Olorode and Okoli, 1978). The genus Crassocephalum is similar to Senecio, but differing in non-possession of ray florets and presence of short bracts. The leaves of species in the genus are typically tooted and hairy in appearance, but all parts are soft and not spiny (Hyde and Wursten, 2007).

Several reviews have been made on the tribe Senecioneae (Asteraceae) resulting in modifications. This has necessitated the splitting of the genus Senecio into 
several genera (Jeffrey, 1992; Nordenstam and Pelser, 2005). A few Peruvian species of Senecio were transferred to other genera such as Dendrophobium, Aequatorium, and Pentacalia. A taxonomic positioning of C. biafrae endemic to the southwest Nigeria has always been unclear. Olorode and Okoli (1978) reported that $C$. biafrae was discussed in their paper only because it falls in the similar utilitarian categories as vegetables with other species investigated. This statement further enhanced some doubts about the taxonomic relationship between $C$. biafrae and these other three species. A call for more reports for a better understanding on the morphological variation and reproductive mechanism in the genus was long suggested (Olorode and Okoli, 1978). A review of literature revealed that some of Nigeria species of Crassocephalum were not clearly delimited, their delimitation having been based upon relatively few and poorly understood characters. A careful handling of morphological data is reported to be one of the trustworthy approaches in assessing evolutionary relationships (Cabrera, 1976; Dutta, 1988).

The roots and leaves of Crassocephalum are popular pot herbs and are indispensable part of human diets in many parts of the world particularly in Tropical Africa (Dairo and Adanlawo, 2007). Some species of Crassoscephalum are known for their medicinal values as juices extracted from their leaves and applied to fresh cuts to stop or minimize bleeding (Gbile and Adesina, 1986; Gulliie et al., 2004). It is also reported to significantly contribute to the dietary vitamin and mineral intakes of local populations (Smith and Eyzaguirre, 2007).

The objective of this study is to compare and document the observed taxonomic variations in morphological attributes considered of taxonomic significance for delimitation of $C$. biafrae and three other species of Crassocephalum namely: $C$. rubens, $C$. crepidioides, and $C$. togoense. This is with a view to showing that problems exist in the traditional or orthodox placement of species into the genus Crassocephalum and to try to outline some possible solutions.

\section{MATERIALS AND METHODS}

\section{Survey of locations of Crassocephalum plant populations}

Series of field trips covering different ecological locations in southwestern Nigeria (Table 1) were made between January 2006 and December 2007. Achenes were collected from field populations of Crassocephalum. Materials collected from different populations were labeled with different accession numbers. There were 23 accessions in all. Specimen plants from these populations had their identities confirmed using Herbarium specimens at the Forestry Research Institute of Nigeria (FRIN) and Obafemi Awolowo University (OAU) Ile-Ife, Nigeria.

\section{Cultivation of specimen plants}

Ten to twenty achenes of each accession were planted in sterilized topsoil contained in polyethylene bags- five bags per accession. They were arranged $1 \mathrm{~m}$ apart in four rows at the Department of Biological Sciences experimental garden, University of Agriculture, Abeokuta, Ogun State, Nigeria. The germinated seedlings were nurtured till flowering.

\section{Studies on the morphological attributes}

Observations of morphological traits were carried out by visual evaluation of qualitative (non-measurable) attributes. These traits include: growth habit, stem texture, leaf texture, leaf shape, leaf margin, leaf apex, achene texture and shape, intensity of odour and pigmentation of flowers at flowering.

The quantitative (measurable) characters were measured and recorded on all accessions at the experimental garden. These traits include: plant height at flowering, leaf length, leaf width, stipule length and width, petiole length, internodes length and peduncle length, by methods described by Faust (1972) and modified by Ayodele (1997).

\section{Analysis of data}

The means generated from the data obtained on the quantitative characters were subjected to statistical analysis using SAS/PC 9.1 package to compute correlation coefficients of all the morphological characters studied. Dendrograms were constructed for all the accessions of the species studied based on similarities and differences in the morphological characters (Milligan, 1987). Means and standard deviations were taken to compute the ranges of all measurable characters for each species.

\section{RESULTS}

Morphological variations in $C$. rubens, $C$. crepidioides, C. togoense, and C. biafrae

Data on the morphological characters of the four species of Crassocephalum studied are presented in Tables 2 and 3. The four species of Crassocephalum exhibited considerable variations and overlaps in most of their morphological characters. All the species are erect annual herbs except $C$. biafrae, which is perennial with climbing (twinning habit). Variations in leaf measurements within and between species were quite obvious (Plates 1 and 2, and Tables 2 and 3). Plant height at flowering was highest in C. biafrae (49.0 to 52.0 $\mathrm{cm}$ ) while $C$. rubens recorded the shortest plant height at flowering $(6.0$ to $8.0 \mathrm{~cm})$ (Table 3). C. crepidioides had the longest leaf length $(14.6$ to $18.9 \mathrm{~cm})$ while leaf length was shortest in $C$. rubens $(7.9$ to $12.6 \mathrm{~cm})$. The widest leaf width was $(8.6$ to $12.0 \mathrm{~cm})$ in $C$. biafrae and least in C. rubens $(4.1$ to $6.7 \mathrm{~cm}$ ). Other records of morphological characters for species delimitation can be found in Tables 2 and 3.

\section{Correlation among morphological characters}

Table 4 explains the correlation coefficients of the morphological characters. Leaf length and stipule length 
Table 1. Population, location and collection data of $C$. crepidioides, $C$. rubens, $C$. biafrae and $C$. togoense.

\begin{tabular}{|c|c|c|}
\hline $\begin{array}{l}\text { Name and accession number of } \\
\text { species }\end{array}$ & Location of collection & Description of location \\
\hline $\begin{array}{l}\text { C. crepidioides (Benth.) S. Moore } \\
\text { AS } / 010,012,015,018 \text {, and } 022\end{array}$ & $\begin{array}{l}\text { Routes: Osiele Village, along Ibadan-Abeokuta Road, No. 21, Gbada } \\
\text { Salami Street, Idimu Lagos, Adodo Village, Igbeti/Ogbomoso, Aguo } \\
\text { Village Ibadan-Oyo Road, University of Ado-Ekiti campus. }\end{array}$ & $\begin{array}{l}\text { Guinea and derived savannah in } \\
\text { yam/Maize farmland, vegetable garden, } \\
\text { waste place, roadside }\end{array}$ \\
\hline $\begin{array}{l}\text { C. rubens (Juss. Ex Jacq.) S. } \\
\text { Moore (purple floret) AS/001, 004, } \\
005,009,014 \text {, and } 017\end{array}$ & $\begin{array}{l}\text { Routes: Guguru Village along Igbeti/Ogbomoso Adodo Village, near } \\
\text { Ogbomoso, Obantoko/Adatan,Asero, Abeokuta, Okuku, along } \\
\text { Ikirun/llorin Road. Guguru Village, near Ogbomoso/lgbeti, roadside, } \\
\text { besides Local Government Secretariat, Epe. }\end{array}$ & $\begin{array}{l}\text { Derived and Guinea savannah in } \\
\text { yam/maize farm, road side, yam/pepper } \\
\text { farmland, cleared land }\end{array}$ \\
\hline $\begin{array}{l}\text { C. rubens (Juss. Ex Jacq.) S. } \\
\text { Moore (light purple floret) AS/002, } \\
003,006,007 \text { and } 016\end{array}$ & $\begin{array}{l}\text { Routes: Telemu Village along Iwo-Osogbo Road, Gurugu Village, along } \\
\text { Ogbomoso/lgbeti, Aramoko-Ado-Ekiti Road. Joju Village, Sango-Otta } \\
\text { along Abeokuta-Lagos, Awe/lwo. }\end{array}$ & $\begin{array}{l}\text { Guinea and derived savannah in yam } \\
\text { farmland, waste place by the roadside, } \\
\text { abandoned plot of land, uncultivated burnt } \\
\text { forest }\end{array}$ \\
\hline $\begin{array}{l}\text { C. rubens (Juss. Ex. Jacq.) S. } \\
\text { Moore (white floret) AS/013, } 019 \\
\text { and } 020\end{array}$ & $\begin{array}{l}\text { Routes: Igbeti township, Oru/ljebu lgbo Road. Ibadan/Abeokuta; Bakatari } \\
\text { Township }\end{array}$ & $\begin{array}{l}\text { Guinea and derived savannah in Yam } \\
\text { farmland, waste place roadside in } \\
\text { dilapidated building }\end{array}$ \\
\hline $\begin{array}{l}\text { C. biafrae (Olive \& Hiern) } \\
\text { S. Moore AS/008 and } 011\end{array}$ & Routes: Fiditi along Oyo-Ibadan Road, Moniya & $\begin{array}{l}\text { Derived SAVANNAH with loamy soil; Cocoa } \\
\text { plantation. }\end{array}$ \\
\hline $\begin{array}{l}\text { C. togoense C.D. Adams AS/021 } \\
\text { and } 023\end{array}$ & Routes: Apomu Ikire; Eleekara, via Idi-Igba, Ilora, Ibadan-Oyo Road. & $\begin{array}{l}\text { Derived savannah with sandy loamy soil; } \\
\text { abandoned farmland and weedy roadsides. }\end{array}$ \\
\hline
\end{tabular}

Table 2. Qualitative morphological characters of Crassocephalum species studied.

\begin{tabular}{|c|c|c|c|c|}
\hline $\begin{array}{l}\text { Morphological } \\
\text { characters }\end{array}$ & C. crepidioides & C. rubens & C. togoense & C. biafrae \\
\hline Growth habit & $\begin{array}{l}\text { Stout erect, low branching, annual } \\
\text { herb with soft root stock. }\end{array}$ & $\begin{array}{l}\text { Erect, low branching, annual } \\
\text { herb with thin non-woody but } \\
\text { tough root stock. }\end{array}$ & $\begin{array}{l}\text { Erect, apical branching, annual } \\
\text { herb with soft root stock. }\end{array}$ & $\begin{array}{l}\text { Twinning perennial with soft } \\
\text { root stock. }\end{array}$ \\
\hline Stem & $\begin{array}{l}\text { Green with purple pigmentation, } \\
\text { pubescent or hairy, succulent, } \\
\text { tendered and soft. }\end{array}$ & $\begin{array}{l}\text { Green, occasionally purple } \\
\text { pigmentation in purple and light } \\
\text { purple type, pubescent or hairy, } \\
\text { thin non-woody but tough. }\end{array}$ & $\begin{array}{l}\text { Green with purple pigmentation, } \\
\text { pubescent or hairy, succulent, } \\
\text { tendered and soft. }\end{array}$ & $\begin{array}{l}\text { Green, glabrous, purple } \\
\text { pigmentation, thick but } \\
\text { succulent. }\end{array}$ \\
\hline Leaves & $\begin{array}{l}\text { Lobed, lyrate or elliptic-pinnatifid, } \\
\text { serrated or coarsely toothed margin, } \\
\text { acute apex, alternate, pubescent or } \\
\text { hairy, } 1-2 \text { lobed, Stipulate. }\end{array}$ & $\begin{array}{l}\text { Elliptic, highly variable serrated } \\
\text { or coarsely toothed margin, } \\
\text { acute apex, alternate, } \\
\text { pubescent or hairy, Stipulate. }\end{array}$ & $\begin{array}{l}\text { Parted or deeply lobed, serrated } \\
\text { and coarsely toothed margin, } \\
\text { acute apex, alternate, pubescent } \\
\text { or hairy, } 4-5 \text { lobed, Stipulate. }\end{array}$ & $\begin{array}{l}\text { Triangular or deltoid, serrated, } \\
\text { sometimes lobed, acuminate } \\
\text { apex, alternate, glabrous or } \\
\text { smooth, exstipulate. }\end{array}$ \\
\hline
\end{tabular}

Table 3. Summary data on the quantitative morphological characters of Crassocephalum species studied.

\begin{tabular}{lcccc}
\hline Characters & C. rubens & C. biafare & C. crepidioides & C. togoense \\
\hline Plant height $(\mathrm{cm})$ & $6.0-8.0$ & $49.0-52.0$ & $6.0-12$ & $6.0-11.0$ \\
Leaf length $(\mathrm{cm})$ & $7.9-12.6$ & $9.5-11.3$ & $14.6-18.9$ & $12.5-15.0$ \\
Leaf width $(\mathrm{cm})$ & $4.1-6.7$ & $8.6-12.0$ & $7.7-9.5$ & $6.2-7.2$ \\
Stipule length $(\mathrm{cm})$ & $1.2-2.9$ & Exstipulate & $1.8-3.9$ & $2.1-2.2$ \\
Stipule width $(\mathrm{cm})$ & $0.8-1.1$ & Exstipulate & $1.4-1.9$ & $0.9-1.1$ \\
Intrenode length $(\mathrm{cm})$ & $1.9-7.0$ & $5.8-5.9$ & $4.1-5.0$ & $3.4-3.8$ \\
Petiole length $(\mathrm{cm})$ & $0.7-1.9$ & $5.4-6.1$ & $3.7-4.2$ & $2.3-2.9$ \\
Peduncle length $(\mathrm{cm})$ & $20.1-35.1$ & $7.0-8.7$ & $3.6-16.1$ & $16.1-24.2$ \\
\hline
\end{tabular}



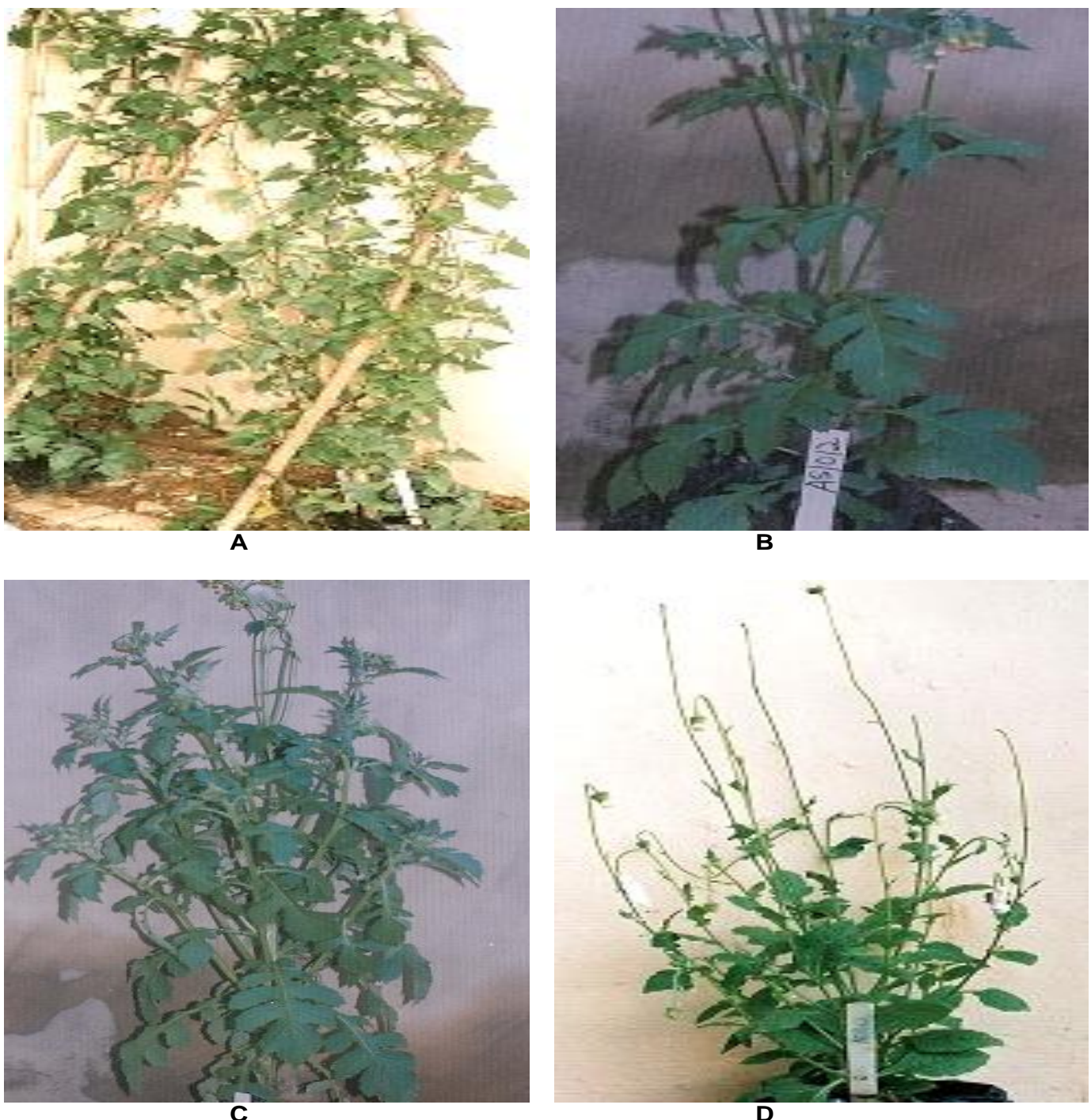

Plate 1. Growth habit of Crassocephalum species studied. A) C. biafrae B) C. togoense C) C. crepidioides D) C. rubens.

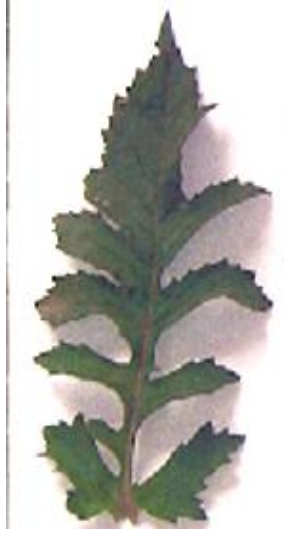

A

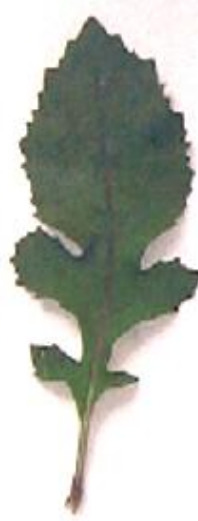

B

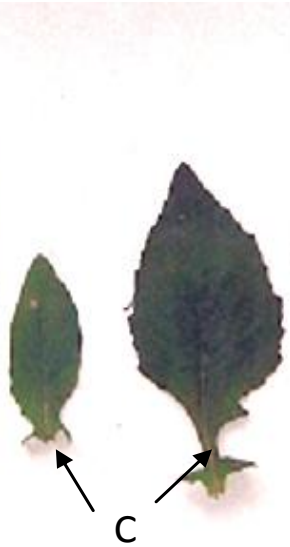

$\mathrm{C}$

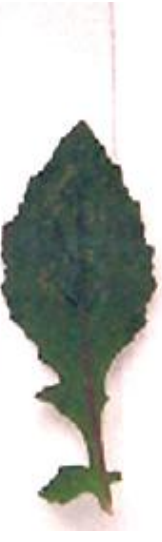

D

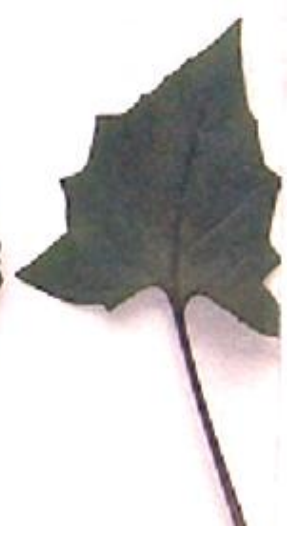

$\mathrm{E}$

Plate 2. Leaf forms in the Crassocephalum species studied A) Parted/ deeply lobed leaf in C. togoense, B) Lobed leaf in C. crepidioides, C and D) Elliptic leaf in C. rubens (Scale line represents $10 \mathrm{~cm}$ ), E) Triangular leaf in C. biafrae. 
Table 4. Pearson correlation coefficients for morphological characters of Crassocephalum species studied.

\begin{tabular}{lcccccccc}
\hline Traits & LL & LW & PL & SL & SW & IL & PDL & PH \\
\hline LL & 1 & $0.63^{* *}$ & $0.52^{*}$ & $0.89^{* * *}$ & $0.91^{* * *}$ & -0.17 & $-0.70^{* * *}$ & -0.01 \\
LW & & 1 & $0.91^{* * *}$ & $0.51^{*}$ & $0.53^{*}$ & 0.15 & $-0.53^{*}$ & $0.67^{\star *}$ \\
PL & & & 1 & $0.51^{*}$ & $0.51^{*}$ & 0.21 & $-0.53^{*}$ & $0.77^{* * *}$ \\
SL & & & & 1 & $0.99^{* * *}$ & -0.09 & $-0.76^{* * *}$ & -0.08 \\
SW & & & & & 1 & -0.09 & $-0.78^{* * *}$ & -0.07 \\
IL & & & & & & 1 & 0.11 & 0.32 \\
PDL & & & & & & & 1 & -0.02 \\
PH & & & & & & & & 1 \\
\hline
\end{tabular}

$0.0001{ }^{* * *}$ highly significant, $0.01{ }^{* *}$ very significant, $0.05=^{*}$ significant, $<0.05=$ not significant $(\mathrm{ns}) . \mathrm{LL}=\mathrm{Leaf}$ length $(\mathrm{cm}), \mathrm{LW}=$ Leaf width $(\mathrm{cm}), P L=$ Petiole length $(\mathrm{cm}), S L=$ Stipule length $(\mathrm{cm}), S W=$ Stipule width $(\mathrm{cm}), I L=I n t e r n o d e$ length $(\mathrm{cm}), \mathrm{PDL}=$ Peduncle length $(\mathrm{cm})$ and $\mathrm{PH}=$ Plant height $(\mathrm{cm})$.

were highly significantly correlated with leaf width $(r=0.89)$ and stipule width $(r=0.91)$. Leaf width was also significantly correlated with petiole length $(r=0.91)$ at probability level of $P<0.001$, petiole length $(r=0.53)$ $\mathrm{P}<0.01$ was significant with internode length and plant height (Table 4). The dendrogram clearly puts the accessions in different cluster groups that reflect their phenotypic and phylogenetic relationships (Figure 1).

\section{Taxonomic attributes of Crasocephalum species studied}

\section{Crassocephalum crepidioides (Benth.) S. Moore (Yoruba: Ebolo)}

C. crepidioides is an erect, low branching annual herb, 6.0 to $12.0 \mathrm{~cm}$ tall with soft root stock. The stem is green sometimes with purple pigmentation when the plant is young or at flowering. Leaves lyrate or elliptic pinnatifid, lobed with 1-2 lobes, serrated or coarsely toothed margin, acute apex, alternate, pubescent 14.6 to $18.9 \mathrm{~cm}$ long and 7.7 to $9.5 \mathrm{~cm}$ broad, stipule length ranging from 1.8 to $3.9 \mathrm{~cm}$ long and 1.4 to $1.9 \mathrm{~cm}$ wide, the petiole length is between 3.7 to $4.2 \mathrm{~cm}$ long, peduncle on which the multiple heads are borne is between 3.6 to $16.1 \mathrm{~cm}$ long (Tables 2 and 3). C. crepidioides usually occurs in fairly large populations in open waste places, abandoned lands or along roadsides in almost all vegetation zones in southwestern Nigeria.

\section{Crassocephalum rubens (Juss.ex.Jacq) S. Moore (Yoruba: Ebure, Ebire)}

C. rubens is an erect, low branching, annual herb 6.0 to $8.0 \mathrm{~cm}$ tall, thin, non-woody but with tough root stock. Green stem with occasionally purple pigmentation especially in purple and light purple floret varieties, pubescent. Leaves 7.9 to $12.6 \mathrm{~cm}$ long, often smaller, highly variable, elliptic, sometimes auriculate, serrated or coarsely toothed margin, pubescent, acute apex; peduncle 20.1 to $35.1 \mathrm{~cm}$ long (Tables 2 and 3). Three varieties were observed in $C$. rubens based on floret colour. There were purple, light purple and white floret morphotypes.

\section{Crassocephalum togoense C.D. Adams}

C. togoense is an erect, apical branching, annual herb of 6.0 to $11.0 \mathrm{~cm}$ tall with soft root stock. The stem is green, purple pigmented when the plant is young and at flowering, pubescent, succulent, but thicker than $C$. crepidioides. Leaves elliptic-pinnatifid, serrated or with coarsely toothed margin, acute apex, pubescent, lobed with 3 to 4 pairs of elliptic segments cut down nearly to the midrib and larger towards the apex, 12.5 to $15.0 \mathrm{~cm}$ long, 6.2 to $7.2 \mathrm{~cm}$ broad, petiole length 2.3 to $2.9 \mathrm{~cm}$ long, stipule 2.1 to $2.2 \mathrm{~cm}$ long, 0.9 to $1.1 \mathrm{~cm}$ broad, terminal and axillary peduncles with multiple capitula ranging from 2.3 to $2.9 \mathrm{~cm}$ long (Tables 2 and 3 ).

\section{Crassocephalum biafrae (Oliv. \& Hiern.) S. Moore (Yoruba: Worowo)}

C. biafrae is twinning perennial herb, usually supported by stake, up to 49.0 to $52.0 \mathrm{~cm}$ tall. The stem is green with purple pigmentation at flowering, thick but nonwoody and glabrous, basal branch is sometimes formed, leaves triangular or deltoid with petiole of 5.4 to $6.1 \mathrm{~cm}$ long, sometimes pinnatifid with deep lobes cut down up to the midrib (Plate 3), serrated or coarsely toothed margin, acuminate apex, alternate, glabrous or smooth, 9.5 to $11.3 \mathrm{~cm}$ long, 8.6 to $12.0 \mathrm{~cm}$ broad, exstipulate, peduncle 7.0 to $8.7 \mathrm{~cm}$ long (Tables 2 and 3). It is a shade tolerant twinner, usually found growing in cocoa plantations. 


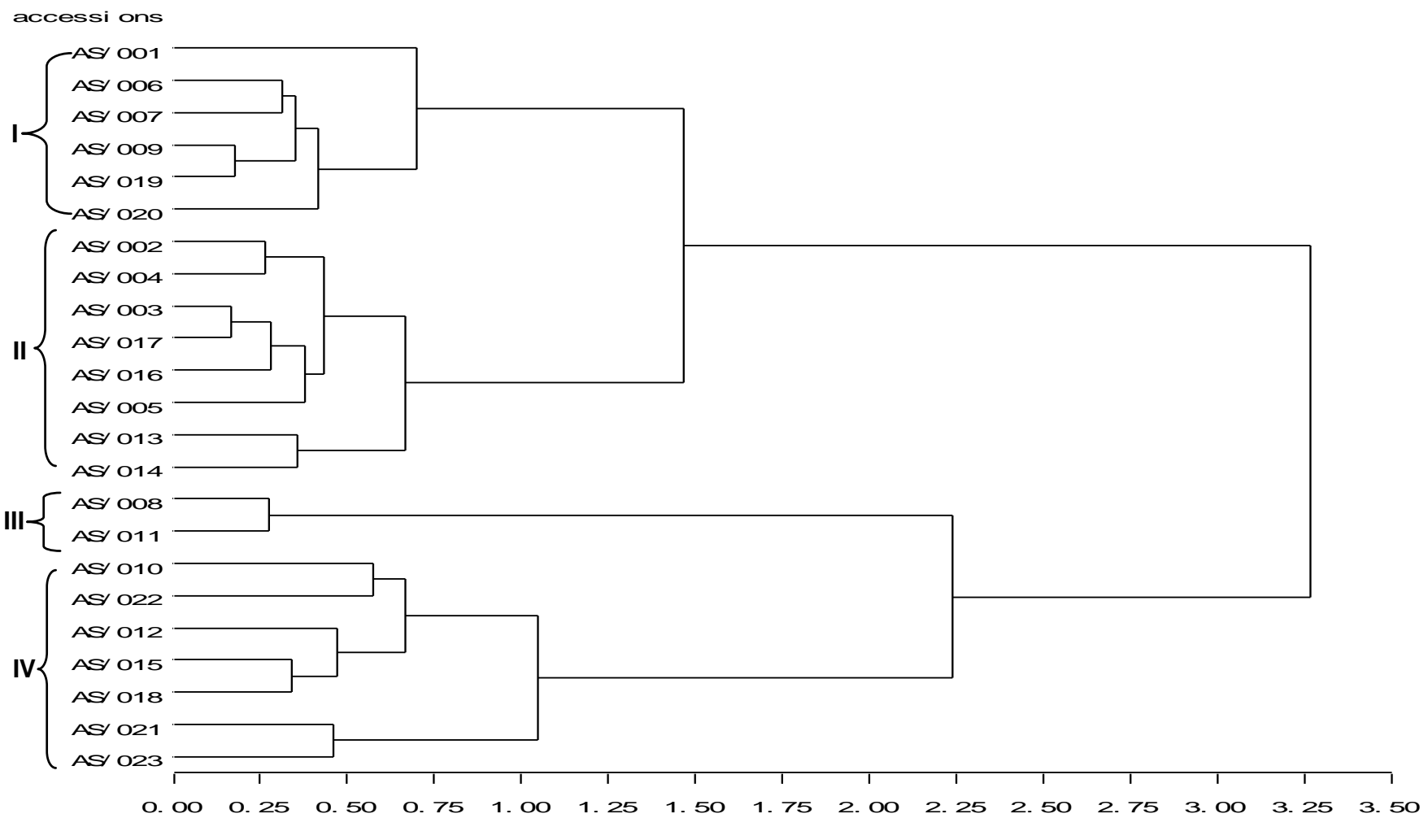

Keys:

\begin{tabular}{ccl}
\hline Groups & Accessions & Species \\
\hline 1 & $\mathrm{AS} / 001,006,007,009,019, \&$ 020 & C. rubens \\
II & $\mathrm{AS} / 002,004,003,017,016,005,013 \& 014$ & C. rubens \\
III & $\mathrm{AS} / 008 \& 011$ & C. biafrae \\
IV & $\mathrm{AS} / 010,022,012,015,018,021 \& 023$. & C.crepidioides \& C. togoense \\
\hline
\end{tabular}

Figure 1. Dendrogram showing grouping of Crassocephalum accessions studied based on morphological characters.

\section{DISCUSSION}

Accessions of C. togoense, C. crepidioides, and $C$. rubens were all erect annual herbs while those of $C$. biafrae, were perennial with twinning habit. The three more similar species can be readily distinguished from $C$. biafrae using their morphological traits such as leaf length, leaf width, petiole length, stipule length, stipule width, internode length, peduncle length, leaf texture, leaf shape, leaf margin, and plant height. Variation in stem texture, leaf - shape, size, and texture, were quite obvious among accessions of the three similar species and between them and C. biafrae (Plates 1 and 2). The morphological attributes dendogram grouping of $C$. crepidioides and $C$. togoense [Figure (1) IV] in addition to their ecological association suggests the co-evolution of the two species and justifies their grouping into the same genus. The form of the pair of segment of leaves at the base is a trait which distinguishes $C$. togoense from $C$. crepidioides while $C$. rubens appears to be intermediate between the two species (Plate 2A, B, C and D).

Morphological attributes constitute the orthodox tool of the Taxonomists because of their diagnostic value in taxonomic evaluation (Cabrera, 1976; Dutta, 1988; Ayodele and Olorode, 2005). It must however be borne in mind that the morphology of an organism is not simply an accident. It represents the result of a long evolution of successive adaptation of living things to their environment (Baldauf, 1965). Azevedo-Goncalves and Matzenbacher (2005) citing Cabrera (1976) considered characters as leaf shape and pubesence stem and plant size, capitula size, stem ramification, fruit size as characters of taxonomic value in species classification. Three of the four species of Crassocephalum studied except $C$. biafrae, showed many common morphological characters which established their genetic and 


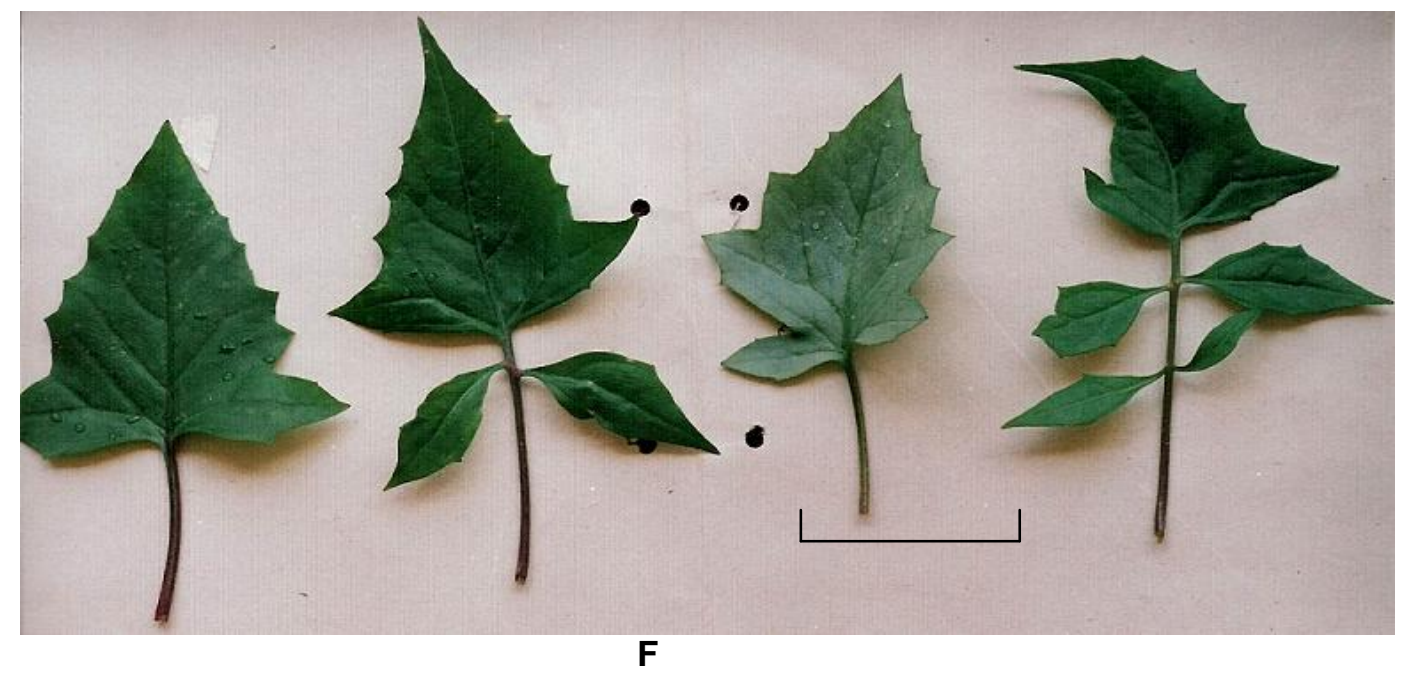

Plate 3. Variable leaf forms in C. biafrae (Scale line represents $5 \mathrm{~cm}$ ).

phylogenetic relationship (Tables 2 and 3 ).

The cluster analysis of the dendrograms also gathered large number of units into smaller number of mutually exclusive groups, each having members that were closely related. $C$. biafrae stands out as a separate species until it got to a flexible beta-value of 2.25 (Figure 1). This further suggests their phenotypic differences. All these observed inter-specific differences were genetic rather than environmental since all the accessions were raised in the same environment and subjected to similar cultural practice. This eliminated the influence of the environment on the phenotypic expressions of their characters.

The leaf and stem texture were usually pubescent for $C$. togoense, $C$. crepidioides, and C. rubens, while glabrous in $C$. biafrae. Acuminate leaf margin was observed for $C$. biafrae while it was acute in the other three species. There were conspicuous differences in leaf shape and growth habit among the four species but however, with some degree of overlap among $C$. togoense, $C$. crepidioides, and $C$. rubens. C. biafrae was distinct from them (Table 2 and Plates 1 and 2). In the flora of West Tropical Africa, Hutchinson and Dalziel (1963) described the genus Crassocephalum on the account of the presence of hairs on both sides of the leaves and stem, acute apex, elliptic-pinnatifid leaf shape, erect, and annual in growth habit. C. biafrae was listed among the species in the genus with the descriptions that were exactly the same with the morphological features observed for accessions of plant materials used in this study. Its inclusion in the genus was viewed as a contradiction.

However, it was observed that $C$. crepidioides, $C$. rubens and $C$. togoense attributes agreed with the descriptions made by Hutchinson and Dalziel (1963) for the genus. C. biafrae on the other hand was observed to be readily separated from the genus Crassocephalum by absence of hairs on both sides of the leaves and stem, acuminate leaf apex, triangular leaf shape, glabrous in texture and perennial climbers. Therefore, these attributes clearly separate $C$. biafrae from other three taxa and is not viewed as to be closely related to other taxa in the genus Crassocephalum. From this study based on $C$. biafrae strikingly distinctive morphological characteristics, infrageneric segregation in the genus is suspected. Therefore, infrageneric group for $C$. biafrae from the genus Crassocephalum is hereby suggested. However, the sub group to which $\mathrm{C}$. biafrae be transferred to requires additional studies. At present we refrain from providing a complete account of the infrageneric taxonomy of this genus but $C$. biafrae is suspected to be infrageneric taxa within the genus. It is hoped that this study will provide the basis for the future work on the delimitation of this genus.

\section{REFERENCES}

Adams CD (1963). Compositae. In: Hepper, F.N. (Editor). Flora of West Tropical Africa. Crown Agents for Oversea Government and Administration 4. Millbank, London, SW1, United Kingdom 2 (2):225297.

Ayodele MS (1997). Studies on the reproductive biology of Vernonia Schreb. (Asteraceae). 1V: Seasonal flowering sequence among plant forms of Vernonia in Nigeria. Comp. Newslett. 30:5-14.

Ayodele, MS, Olorode O (2005). A biosystematic evaluation of the relationship between three allopatric shrubby species of Vernonia Schreb. (Asteraceae) in Nigeria. Comp. Newslett. 42:8-25.

Azevedo-Goncalves CF, Matzenbacher NI (2005). Taxonomy notes in Hypochaeris L. (Asteraceae). Comp. Newslett. 42:1-4.

Baldauf JR (1965). A comparative study of the pectoral girdle in the Hyliade. Res. Prob. In. Biol. Sci. Series 1. Am. Inst. Biol. Sci. Curr. Study 3:9-17.

Cabrera AL (1976). Materials para una revision del genero Hypochaeris. 1. Hypochaeris chillensis (H. B. K.) Hieron. Darw. 20(4):312-322.

Dairo FAS, Adanlawo IG (2007). Nutritional quality of Crassocephalum crepidioides and Senecio biafrae. Pak. J. Nutr. 6(1):35-39. 
Dutta SC (1988). Evolution In: Systematic Botany. Wiley Eastern Limited, Indian 4:447-450.

Faust WZ (1972). A biosystematics study of the Interiores species group of the genus Vernonia (Compositae). Brittonia 24:362-378.

Gbile ZO, Adesina SK (1986). Nigerian flora and its pharmaceutical potentials. J. Ethnopharm. 19:1-16.

Gulliie MA, Ogiiteu H, Segul M., Karaman I, Sahin F (2004). Antimicrobial effect of Quercus ilex L. extract. Phytother. Res. 8:208211.

Hutchinson JJ, Dalziel JM (1963). Flora of West Tropical Africa. Revised F. N. Hepper, Crown Agents, London 2:244-248.

Hyde MA, Wursten B (2007). Flora of Zimbabwe: Genus Crassocephalum http://www Zimbabwe flora.co.zw/species data/genus.php.

Jeffrey C (1992). The tribe Senecioneae (Compositae) in the Mascarene Islands with an annotated world check-list of genera of the tribe. Notes Compositae VI. Kew Bull. 47(1):49-109.

Milligan R (1987). A study of the Beta-Flexible Clustering Method. Multivar. Behav. 24(2):163-176.
Nordenstam B, Pelser PB (2005). Dauresia and Mesogramma: One new and one resurrected genus of the Asteraceae- Senecioneae from Southern Africa. Comp. Newslett. 42:74-83.

Olorode O, Okoli BB (1978). Cytogenetic studies in some Nigerian species of Crassocephalum (Senecioneae- Compositae). Nig. J. Genet. 2:81-90.

Smith FI, Eyzaguirre P (2007). Africa Leafy vegetables: Their Role in the World Health Organization Global Fruit and Vegetable initiative. Africa J. Food Agric. Nutr. Dev. 48:75-85. 